\title{
Attitude of Male Inservice and Preservice Early Childhood Teachers Towards Working in Preschool Centers in Ibadan, Nigeria
}

\author{
Amosun Moses ${ }^{1}$, Lawrence Ogunniyi², Ogunbiyi Funke ${ }^{3}$ \\ 1,2,3 University of Ibadan, Nigeria
}

\begin{abstract}
Preschool Education provides the foundation for all-around development, enables the child to understand various issues and fit in well into society. Although it is the duty of both male and female early childhood educators to help children develop holistically, statistics have shown that more female caregivers work in preschool centers across the country than males. Even in some foreign countries, this problem remains the same. However, researchers have tried to identify the cause of this gender inequality or disparity but have only sampled the opinion of others about this without adequately considering the attitude of the male early childhood educators. Hence, this study aimed at investigating the attitude of male early childhood educators towards working in preschool centers in Ibadan. The study adopted a mixed-method research approach, and the design is an explanatory triangulation of QUAN + QUAL type. A proportional stratified sampling technique was used to select 150 in-service and 150 pre-service male early childhood educators from the 3 local government areas selected. One instrument was used to gather the quantitative data. Interviews of in-services and pre-service early childhood educators also form a source of qualitative data. The study found out that the attitude of early childhood educators is not encouraging. It also found out that there is no significant difference between in-services and preservice early childhood educators in their attitude towards working in a preschool. It was recommended that investment should be made into early childhood education levels so as to make the salary attractive for most male educators.
\end{abstract}

Keywords: Attitude, early childhood teachers, working, preschool centers, in-service, pre-service

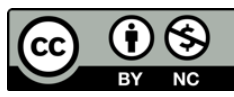

This is an open access article under the CC-BY-NC license.

\section{INTRODUCTION}

Early childhood education is referred to as the most important structure on which another level of education should be laid. It is the most rapid period of development in a human's life and is critical to a child's cognitive, social, emotional, and physical development. According to Salami, Olaniyan, Bankole, \& Falola (2016), the early years are the most significant period to the formation of intelligence, personality, social and emotional behavior of a child. This level of education comprises crucial programs and activities which are critical to holistic development, academic success, and future achievements of children. It is also recognized by the federal government of Nigeria as a foundational and essential program that Nigerian children must experience (Akinrotimi \& Olowe, 2016).

However, the effort to make Early Childhood Education (ECE) effective, functional and appropriate rests on all (Salami, 2016). This implies that if Early Childhood Education, especially Pre-primary or Preschool Education, would achieve its set goals towards the overall development of children, it would involve the effort of stakeholders as well as caregivers regardless of their gender. But this has not been the case as there has been gender imbalance in the pre-school teaching profession and feminization of the profession all over the world. (Mukuna \& Motsotso, 2011). In support of this view, the summary of a few selected states within Nigeria where the number of female ECCDE teachers overwhelmingly overshadows their male counterparts in public schools as of 2016 are shown below in table 1.0:

Corresponding author amosunmoses@gmail.com; lawrenceogunniyi@gmail.com; Funkeogunbiyi74@yahoo.com DOI: https://doi.org/10.31098/ijeiece.v3i2.536 
Table 1.0: Summary ECCDE teachers in a few selected states within Nigeria

\begin{tabular}{llllll}
\hline & \multicolumn{2}{l}{ ECCDE TEACHERS } & & \multicolumn{2}{l}{ ECCDE TEACHERS } \\
\hline State & Male & Female & State & Male & Female \\
Abia & 0 & 1,860 & FCT-Abuja & 35 & 559 \\
Anambra & 96 & 2,169 & Plateau & 640 & 1,022 \\
Edo & 98 & 1,415 & Ondo & 628 & 1,447 \\
Ogun & 334 & 2,729 & Kwara & 256 & 1,110 \\
Oyo & 365 & 2,582 & Imo & 597 & 3,442 \\
Ekiti & 599 & 1,940 & Cross-River & 633 & 1,664 \\
Ebonyi & 419 & 1,132 & Delta & 701 & 2,938 \\
Adamawa & 697 & 1,176 & Akwa-Ibom & 446 & 1,335 \\
Enugu & 135 & 763 & Nasarawa & 283 & 748 \\
\hline
\end{tabular}

Source: Universal Basic Education Commission (UBEC) in National Bureau of Statistics,(2016)

In addition to these facts, reports by the NBS in 2016 also reveal that as at the time of the report, the total number of all-female ECCDE teachers in Nigeria stands at 38,567 while the male ECCDE Population is at a lesser rate of 18,021 . This implies that there are more female preschool teachers than male preschool teachers in Nigeria. This is in line with SDG goal 5, which advocates gender equality in favor of women. However, this is not the case here, as there seems to be an imbalance because men are not included or emphasized as benefactors of this goal.

The implication is that since Gender balance among the ECCDE teaching staff is vital to promoting gender parity and equality in access to and achievements in education if necessary steps are not taking towards addressing the issue, the needed supportive and non-discriminatory learning environment for both boys and girls would not be achieved (NBS, 2016). Moreso, this female-based dominance has led to some problems about males' participation in the field of pre-school education (Sumsion, 2000). Erden, Ozgun \& Ciftci (2011) were of the opinion that gender imbalance could affect the behavior of children regardless of their gender.

Male teachers, however, are important and should be supported for three main reasons. First, the absence of fathers in children's life. In some societies, many children grow up in families with a single parent, usually the mother. There is a growing need for males to take more active roles in children's lives (Cameron 2001; Haris \& Barnes, 2009). Second, males could also be positive role models for little ones. Male pre-school Education teachers can be taken into account as sources of role models, especially for boys (Cameron, 2001; Martino, 2008; Skelton, 2005; Sumsion, 1999). Male teachers could also be positive role models for healthy gender identity and gender-related issues in societies (Cameron, 2001). A male role model is important not only for boys but also for girls. The last point is gender equality. If we could balance the number of male and female teachers, this may help children to develop more positive behaviors inside and outside of class settings (Cameron, 2001).

There have been many reasons this gender disparity seems to be dragging over the years. One of them is the attitude of people towards ECCDE, which is that of suspicion with which they are greeted (Cooney \& Bittner, 2001; Farquhar, 1997; Rodriguez, 1997; Sargent, 2002; Smedley \& Pepperell, 2000). Also, men who teach young children fear their motives are being misinterpreted, so they find themselves 
Amosun Moses, Lawrence Ogunniyi, Ogunbiyi Funke

constantly monitoring what they say or how they touch children (Rodriguez, 1997). The negative perceptions toward men working with young children cause feelings of discomfort, insecurity, helplessness, and anger (Cooney \& Bittner, 2001; Farquhar, 1997; Sargent, 2002; Smedley \& Pepperell, 2000).

Although researchers have sampled the perception of parents, societal attitudes (Cunningham \& Watson, 2002; Gamble \& Wilkins, 1997; Seifert, 1974), as well as preschool teachers (Bracewell, 2016) but most of these studies are foreign studies. More so, it has been established earlier in the discussion that there have been policies, laws as well as sentimental believes in favor of women's role in early childhood education. Most researchers do not consider the stigmatization of men working as caregivers or preschool teachers. Many of these men have, as a result, formed their own perspectives about the profession leading to the drastic decrease in the population of men in early childhood education. Therefore, this study investigated the attitude of male early childhood educators towards working in preschool centers in Ibadan Metropolis.

\section{LITERATURE REVIEW}

\section{Herzberg's two-factor theory}

Frederick Herzberg's Two-Factor Theory, also known as Motivation and Hygiene theory, was propounded in 1959. Herzberg identified two sets of factors in determining employees working attitudes as well as the level of performance named (Robbins, 2009; Teck-hong \& Amna, 2011). Herzberg noted that full supply of Hygiene Factors would not necessarily result in employees' job satisfaction, but in order to increase employees' performance or productivity, motivation factors must be addressed. Yusoff, Kian \& Idris (2013) argued that Two-Factor Theory is keenly related to Maslow's hierarchy of needs as it introduced more factors to measure how individuals are motivated in their workplace. This is why this theory becomes germane to this study as it investigated the attitude of male early childhood educators towards working in preschool centers. This is because the societal attitude, salary, and even job satisfaction of male caregivers, especially in developing countries such as Nigeria, does not give them the necessary boost needed to compete with their peers in another profession. This, in turn, informs male caregivers' attitude and motivation towards working in preschool centers. Accordingly, if these factors are checked, the presence of motivators can lead to job satisfaction, a positive attitude towards the work situation, and improved productivity (Herzberg, 1966).

\section{Research Questions}

The following research questions were raised to guide the study.

1. What is the attitude of male early childhood educators towards working in preschool centers in Ibadan Metropolis?

2. What are the challenges faced by male early childhood educators in working in preschool?

\section{Hypothesis}

This hypothesis was being tested at 0.05 level of significance

$\mathrm{Ho}_{1}$ : There is no significant difference between male in-service early childhood educators and preservice early childhood educators in their attitude towards working in preschool centers in Ibadan Metropolis. 


\section{RESEARCH METHODOLOGY}

The study adopts an interpretive paradigm with mixed methods research approach in which the design is an explanatory triangulation of QUAN + QUAL type. The mixed-methods approach is adopted so as to enable the researcher to access data through diverse means and in various form, which can be used to cross-validate and support one another (Ary, Jacob, and Sorensen, 2010; Cresswell, 2012). The explanatory triangulation research design of QUAN + QUAL type is described as a design in a mixedmethod approach where both quantitative and qualitative data are collected at the same time and in the almost same volume where findings from the qualitative are used to complement that of quantitative (Ary, Jacob, and Sorensen, 2010).

The population of the study comprises all-male early childhood educators in the Ibadan metropolis. A simple random sampling technique was used to select 3 local government areas from 5 local government areas available in the Ibadan metropolis. A proportional stratified sampling technique was used to select 150 in-service and 150 pre-service male early childhood educators from the 3 local government areas selected. A total sample of 300 male early childhood educators participated in the study.

Data was collected using a self-designed and validated questionnaire titled 'Male Early childhood Attitude Questionnaire, which yielded a reliability coefficient of 0.78 using the Cronbach alpha reliability technique. The instrument contains both sections A and B. Section A contains demographic information such as educational qualification and level of male early childhood educators. While section B contains 15 items on a 4 Likert scale rated; 'Strongly Agree, Agree, Disagree, Strongly disagree' about male early childhood educators' attitude towards working in preschool centers in the Ibadan metropolis. Key Informant Interview Schedule (KIIS) was designed to collect qualitative data. The questionnaires were distributed manually. Face-to-face interview with in-services and pre-service male early childhood educators was conducted to collect the qualitative data. The data were analyzed using descriptive statistics of frequency count, percentage, mean and standard deviation, as well as inferential statistics of T-test. A thematic approach was used to analyze the qualitative data

\section{RESULT AND DISCUSSION}

Research question 1: What is the attitude of male early childhood educators towards working in preschool centres in Ibadan Metropolis?

Table 2.0: Showing the attitude of male early childhood educators towards working in preschool centers

\begin{tabular}{llllllll}
\hline S/N & ITEMS & SA & A & D & S D & Mean & Std.D \\
\hline $\mathbf{1}$ & Working in preschool centers is not & 100 & 106 & 72 & 22 & 2.946 & 0.93 \\
& a man's job & $(33)$ & $(35)$ & $(24)$ & $(8)$ & & \\
$\mathbf{2}$ & I feel working in preschool suits & 161 & 109 & 21 & 9 & 3.406 & 0.75 \\
& females more than men & $(54)$ & $(36)$ & $(7)$ & $(3)$ & & \\
$\mathbf{3}$ & Working in preschool would make & 38 & 114 & 108 & 40 & 2.500 & 0.88 \\
& me feel belittled and unfulfilled & $(13)$ & $(38)$ & $(36)$ & $(13)$ & & \\
\hline
\end{tabular}


International Journal of Emerging Issues in Early Childhood Education (IJEIECE) Vol. 3 (2), 48-56

Attitude of Male Inservice and Preservice Early Childhood Teachers Towards Working in Preschool Centers in

Ibadan, Nigeria

Amosun Moses, Lawrence Ogunniyi, Ogunbiyi Funke

\begin{tabular}{|c|c|c|c|c|c|c|c|}
\hline 4 & $\begin{array}{l}\text { I love early childhood education and } \\
\text { would love to work in preschool. }\end{array}$ & $\begin{array}{l}30 \\
(10)\end{array}$ & $\begin{array}{l}56 \\
(19)\end{array}$ & $\begin{array}{l}171 \\
(57)\end{array}$ & $\begin{array}{l}43 \\
(14)\end{array}$ & 2.243 & 0.82 \\
\hline 5 & $\begin{array}{l}\text { I feel the salary may not be enough } \\
\text { to cater to my family, so I wouldn't } \\
\text { really want to work in preschool }\end{array}$ & $\begin{array}{l}101 \\
(34)\end{array}$ & $\begin{array}{l}134 \\
(45)\end{array}$ & $\begin{array}{l}39 \\
(13)\end{array}$ & $\begin{array}{l}26 \\
(8)\end{array}$ & 3.033 & 0.90 \\
\hline 6 & $\begin{array}{l}\text { I have passion for the job, so salary } \\
\text { does not matter }\end{array}$ & $\begin{array}{l}33 \\
(11)\end{array}$ & $\begin{array}{l}31 \\
(10)\end{array}$ & $\begin{array}{l}137 \\
(46)\end{array}$ & $\begin{array}{l}99 \\
(33)\end{array}$ & 1.993 & 0.94 \\
\hline 7 & $\begin{array}{l}\text { Working in preschool is a well- } \\
\text { respected career. }\end{array}$ & $\begin{array}{l}36 \\
(12)\end{array}$ & $\begin{array}{l}122 \\
(41)\end{array}$ & $\begin{array}{l}108 \\
(36)\end{array}$ & $\begin{array}{l}34 \\
(11)\end{array}$ & 2.533 & 0.85 \\
\hline 8 & $\begin{array}{l}\text { I believe that female early childhood } \\
\text { educators work better with } \\
\text { children, so I do not really fit well in } \\
\text { a preschool class }\end{array}$ & $\begin{array}{l}136 \\
(45)\end{array}$ & $\begin{array}{l}118 \\
(39)\end{array}$ & $\begin{array}{l}42 \\
(14)\end{array}$ & $\begin{array}{l}4 \\
(2)\end{array}$ & 3.286 & 0.75 \\
\hline 9 & $\begin{array}{l}\text { My friends from other profession do } \\
\text { not esteem someone especially } \\
\text { male working in preschool }\end{array}$ & $\begin{array}{l}97 \\
(32)\end{array}$ & $\begin{array}{l}144 \\
(48)\end{array}$ & $\begin{array}{l}45 \\
(15)\end{array}$ & $\begin{array}{l}14 \\
(8)\end{array}$ & 3.080 & 0.81 \\
\hline 10 & $\begin{array}{l}\text { Working in preschool is not easy for } \\
\text { me because, some parents feel they } \\
\text { cannot trust a male teacher with } \\
\text { their children, especially female } \\
\text { children }\end{array}$ & $\begin{array}{l}134 \\
(45)\end{array}$ & $\begin{array}{l}74 \\
(25)\end{array}$ & $\begin{array}{l}67 \\
(22)\end{array}$ & $\begin{array}{l}25 \\
(8)\end{array}$ & 3.056 & 1.00 \\
\hline
\end{tabular}

Note: Percentages are in Parentheses.

Key: SA is Strongly Agree; A is Agree; D is Disagree; SD is Strongly Disagree

Table 2.0 shows the attitude of male early childhood educators towards working in preschool centers in Ibadan Metropolis. Analysis shows that the attitude of both in-service and Pre-service male early childhood teachers was negative as they all felt that; working in preschool centers is not a man's job $(\bar{X}=2.95)$, they feel working in preschool suits females more than men $(\bar{X}=3.41)$, Working in preschool would make them feel belittled and unfulfilled $(\bar{X}=2.50)$, they feel the salary may not be enough to cater for their family, so they wouldn't really want to work in preschool $(\bar{X}=3.03)$, they believe that female early childhood educators work better with children, so they feel that they do not really fit well in preschool class $(\bar{X}=3.29)$, My friends from other profession do not esteem someone especially male working in preschool $(\bar{X}=3.08)$, Working in preschool is not easy for them because, some parents feel they cannot trust a male teacher with their children, especially female children $(\bar{X}=3.06)$, however, they also feel that working in preschool is a well-respected career $(\bar{X}=2.53)$. This supports the findings of Wardle (2003) that males usually avoid a teaching job because of low salary, status, prejudice against male teachers, isolation (Cooney \& Bitter, 2001; Wardle, 2003), and negative appreciation (Wardle, 2003). 
The qualitative data collected do not support the findings from the quantitative analysis. When Mr. X, who is an In-service ECCDE teacher, was asked if he likes to work in a preschool center, his response was affirmative. He further supported his claim by saying:

"I like working in Preschool as a preschool teacher, although being a preschool teacher is a female job, but I do not feel dignified working there as a man. Another thing is that most schools feel men are not capable so the job is naturally given to women instead."

He also stated that many parents are often paranoid when they see a male ECCDE teacher who happens to be their female children's class teacher. He concluded that if he finds an opportunity to work in another level, especially primary, or secondary he would happily seize the opportunity. This supports the findings of Erden, Ozgun \& Ciftci, (2011) that pre-school teaching is traditionally considered to be a female occupation, and society, in general, is biased against males entering pre-school settings as teachers.

Mr. Y, who is a pre-service early childhood educator in one of the Local Governments of the study, affirmed that he wouldn't like to work in any preschool because the salary scale in private schools is very meager. Although he would have loved to work in public preschool centers, employment opportunity there is not readily available. This also support these findings that males have generally avoided careers in early childhood education because of low status (Fagan, 1996) and salaries (Cooney \& Bittner, 2001; Fagan, 1996)

Research Question 2: What are the challenges faced by male early childhood educators in working in Pre School

To answer this research question, qualitative data gathered through interviews will be used. According to the respondents, the challenges faced by male early childhood educators in working in Pre School are listed below. The following challenges were identified as critical to male early childhood educators in working in Pre School:

a. Parents attitudes, especially mothers, towards male early childhood educators working in preschool

b. Low salary, especially in private preschool centers

c. Men's inability to work with children as female ECCDE teachers do

d. Discouragement from the members of the society

These findings support the findings of Ferguson, (2005), who stated that experiences, attitudes related to salary, status, working in a predominantly female environment, and physical contact with children are often the four factors contributing to the decline in the percentage of male Early childhood educators in working in a preschool. Mukuna \& Mutsotso, (2011) also highlighted problems that are in support of the findings being discussed. These are; Low salaries, stereotyping, low respectability, fear of being accused of abuse, low status of the profession.

\section{Hypothesis}

$\mathrm{Ho}_{1}$ : There is no significant difference between male in-service early childhood educators and pre-service early childhood educators in their attitude towards working in preschool centers in Ibadan Metropolis.

Table 4.0: Showing t-test analysis of the difference between male in-service early childhood educators and male pre-service early childhood educators in their attitude towards working in preschool centers 
Amosun Moses, Lawrence Ogunniyi, Ogunbiyi Funke

\begin{tabular}{lccccccc}
\hline Variable & $\mathbf{N}$ & Mean & Std.D & t & df & Sig. & Remark \\
\hline $\begin{array}{l}\text { The attitude of Male Early } \\
\text { childhood Educators }\end{array}$ & & & & & & & \\
In-service & 150 & 28.59 & 2.871 & & & & Significant \\
Pre-service & 150 & 27.57 & 4.256 & & & &
\end{tabular}

Table 4.0 shows that there is a significant difference between male in-service early childhood educators and male pre-service early childhood educators in their attitude towards working in preschool centers in Ibadan Metropolis $(\mathrm{t}=2.45 ; \mathrm{df}=298 ; \mathrm{p}<0.05)$. Therefore, hypothesis 1 is rejected. This implies that there is a significant difference between male in-service early childhood educators and male pre-service early childhood educators in their attitude towards working in preschool centers in Ibadan Metropolis.

This may be so because the qualitative data also supported this fact. In-service male early childhood educators were asked if they like to work in a preschool center; their response was affirmative. One of them claimed by saying:

"I like working in Preschool as a preschool teacher, although being a preschool teacher is a female job, but I do not feel dignified working there as a man."

Most of them prefer to work in preschool and claim that they love working in preschool but may not be entirely happy doing so because they complain about the attitude of people towards them.

Pre-service male early childhood educators, on the other hand, think otherwise. Most of them felt that working in preschool deflates their ego as their friends from other professions do not respect them enough. One of the pre-service male early childhood educators said:

"I do not like working in preschool because the salary is meagre."

This shows that the attitudes of both Pre-service male early childhood educators and In-service male early childhood educators are different. While one believes that they like working in preschool, others do not.

\section{CONCLUSION}

This study investigated the attitude of male early childhood educators towards working in preschool centers in Ibadan. The study found out that most of the attitudes of both Pre-service male early childhood educators and In-service male early childhood educators are different. While one believes that they like working in preschool, others do not. This shows that there is a need to improve the rate at which men are involved in preschool education because their involvement has proven to be very important to children's holistic development.

\section{Recommendations}

In relation to the findings, it was recommended that;

1. In-service early childhood educators should be paid equivalent salaries with others in other fields, such as banking, medicine, and so on

2. Schools should employ more male ECCDE teachers

3. Men should be encouraged to study Early Childhood education for the purpose of practice at the preschool level. 
4. Parents should be informed on the importance of men at the Preschool level.

\section{REFERENCES}

Akinrotimi, A.A and Olowe, P.K (2016). Challenges in Implementation of Early Childhood Education in Nigeria: The Way Forward. Journal of Education and Practice, Vol. 7(7) pp. 33-38

Ary Donald, Jacobs L.C., and Sorensen C. 2010.Introduction to Research in Education. USA: WADSWORTH Cengage Learning.

Bracewell, J .M. (2016). Attitudes of Males about Teaching Grades K-12 in a Public School District. A thesis submitted to Walden University. Retrieved 20 $20^{\text {th }}$ June, 2018 from http://scholarworks.waldenu.edu/dissertations.

Cameron, C. (2001). Promise or problem? A review of the literature on men working in early childhood services. Gender, Work \& Organization, 8(4), pp. 430-453.

Cooney, M., and Bittner, M.T. (2001). Males in early childhood education: Their emergent issues. Early Childhood Education Journal, 29 (2), pp. 77-82.

Creswell, J. W. (2012). Educational Research: Planning, Conducting, and Evaluating Quantitative and Qualitative Research (4th ed.). Boston: Pearson.

Cunningham, B. and Watson, L.W. (2002). Recruiting male teachers. Young Children, 1-5. [Electronic Version].

Erden, S., Ozgun, O., Ciftci, M.A.,(2011). "I am a man, but i am a pre-school education teacher": Self- and social-perception of male pre-school teachers. Procedia Social and Behavioral Sciences 15 pp. 3199-3204

Fagan J (1996). Principles for developing male involvement programs in early childhood settings: a personal experience. Young Children. 51 (4): 64-71.

Farquhar, S. (1997). Are male teachers really necessary? ERIC document No. 417821.

Ferguson, S. (2005). Looking for Mr. chips. Maclean's, 118(10), 50-51. Retrieved from https://maryvican.wordpress.com/2008/02/20/the-advancement-success-andchallenges- of women-in-female-dominated-fields/

Gamble, R.J. and Wilkins, J. (1997). Beyond tradition: where are the men in elementary education? Contemporary Education, 68, 187-193. [Electronic Version].

Haris, K. and Barnes S. (2009). Male teacher, female teacher: Exploring children's perspectives of teachers' roles in kindergartens. Early Child Development and Care, 179( 2),pp. 167-18.

Herzberg, F. (1966). Work and the nature of man. Cleveland: World

Martino, W. J. (2008). Male teachers as role models: addressing issues of masculinity, pedagogy and the re-masculinization of schooling.Curriculum Inquiry, 38(2), pp. 189-223.

Mukuna, T.E and Mutsotso, S.N. (2011), Gender Inequalities in Early Childhood Development Education Teaching Profession in Kenya. International Research Journal of Educational Research. Vol. 2(13) pp. 1876-188.

National Bureau of Statistics, (2016). Social Statistics Report 2016. Federal government of Nigeria

Rodriguez, E. (1997). What does gender have to do with it? Male teachers in early childhood education. ERIC Document No 415979.

Salami, I.A. (2016), Nigerian Early Childhood Education Policies and Practices for Sustainability. European Journal of Research and Reflection in Educational Sciences Vol. 4(5) pp. 71-81 
International Journal of Emerging Issues in Early Childhood Education (IJEIECE) Vol. 3 (2), 48-56

Attitude of Male Inservice and Preservice Early Childhood Teachers Towards Working in Preschool Centers in Ibadan, Nigeria

Amosun Moses, Lawrence Ogunniyi, Ogunbiyi Funke

Salami, I.A., Olaniyan A.O., Bankole O.T. and Falola, O.I. (2016). Preschool education practices in Nigeria: what obtains in public and private schools in Ibadan Metropolis: Revitalisation of Nigerian Educational System for Relevance and Development, M.K. Akinsola, O.A. Moronkola, J.A Ademokoya, I.A Salami (Eds.) Faculty Of Education, University Of Ibadan: pp. 431- 450

Sargent, P. (2002). Under the glass: conversations with men in early childhood education. Young Children, 57(1), pp. 22-30.

Seifert, K. (1974). Perceptions of men in early childhood education. ERIC Document No. 125756.

Skelton, C. (2005). Male primary teachers and perceptions of masculinity. Educational Review, 55(2), pp. 195-209.

Smedley, S. and Pepperell, S. (2000). No man's land: caring and male student primary teachers. Teachers \& Teaching, 6(3), pp. 259-277. Retrieved from Academic Search Elite database.

Sumsion, J. (1999) A Neophyte Early Childhood Teacher's Developing Relationships with Parents: An Ecological Perspective. Early Childhood Research and Practice, Retrieved from Hyperlink http://ecrp.uiuc.edu/v1n1/sumsion.html on 06.12.2010.

Teck-hong, T., \& Waheed, A. (2011). Herzberg's motivation-hygiene and job satisfaction in the Malaysian retail sector: Mediating effect of love of money. Asian Academy of Management Journal. Vol. 16(1): 73-94

Wardle F (2003). Introduction to early childhood education: A multidimensional approach to childcentered care and learning. Boston, MA: Allyn and Bacon.

Yusoff, W,F., Kian, T.S., \& Idris, M,T,(2013). Herzberg's two factors theory on work motivation: does its work for today's environment? Global Journal of Commerce and Management Perspective. Vol.2 (5):18-22 